\title{
MARKETING TRENDS AND PERSPECTIVES ON THE BANK MARKET
}

\author{
Maja Cogoljević184 \\ Tamara Vesić 185 \\ Ljiljana Dimitrijević186
}

https://doi.org/10.31410/itema.2018.464

\begin{abstract}
In contemporary business environment changes that are manifested through deregulation of financial operations, the strengthening of competition in financial services and development of the information system increase business risks both in the domestic and international markets. Basic business goals (financial gain, maximizing profit, growth, development, higher market share, risk avoidance) can only be achieved with maximum adjustment to the changes that are most effectively achieved by strategic management which is based on marketing principles that are focused on meeting customers need. Commercial banks must be market-oriented if they want to ensure survival, growth and development. This paper aims to show that modern banking goes into the process of transformation, especially banking management and business technology. Traditional banking is becoming less important when it comes to the efficient functioning of the financial system.
\end{abstract}

Keywords: Marketing plan, client needs, banking management

\section{INTRODUCTION}

$\mathrm{U}$ ntil the mid-1950s, marketing was seen as being reserved for production activities, and as such bankers did not focus on it. It was only by the end of the 1950s and the beginning of the 1960s that the idea of utilizing marketing expanded to service activities as well. In our part of the world, the application of marketing in service activities (traffic, tourism, banking, insurance, etc) only began in the 1970s. Of course, this initial period of the application of marketing in service activities was not exactly about the concept of marketing, but about the concept of economic advertising and promotion [1]. The results were immediate; the banks that first began advertising managed to attract new depositors and thus increased their deposit potential. These activities affected the competing banks, which were forced to begin with the same marketing activities of their own as soon as possible. This competitive activity neutralized the advantages of the banks that began their advertising activities first. Customer orientation becomes a key aspect of a modern business which is being implemented in order to meet and to win loyal customers [2].

The primary aim of this paper is to raise the public awareness of the specifics of the application of marketing within the banking services sector and to support the successful implementation of business marketing philosophy. The secondary aim of this paper is to inform the public about the effects of marketing on modern banking and to provide answers to basic questions related to providing banking services to clients.

\footnotetext{
${ }^{184}$ Faculty for Business Economics and Entrepreneurship, Mitropolita Petra 8, Belgrade, Serbia

${ }^{185}$ Faculty for Business Economics and Entrepreneurship, Mitropolita Petra 8,Belgrade, Serbia

${ }^{186}$ Faculty for Business Economics and Entrepreneurship, Mitropolita Petra 8,Belgrade, Serbia
} 


\section{MARKETING PLANNING IN A COMMERCIAL BANK}

In market economies during the 1980s there was an increased need within banking and financial institutions for the use of strategic planning leverage as a means of reviewing the market position, and finding the most favorable methods for strengthening these positions in the future as a result of the deregulation of the financial sector, globalization and the increase in competition.

The main reason for planning is the lack of resources. Banks that operate on multiple markets are inevitably introducing a marketing plan that combines the creation of the bank's vision, a strategy for fulfilling this vision and the development of action programs that are used to define priorities, make decisions, set goals, and control the actions taken. Without it, the bank would have an unclear goal and would be unprepared to respond to the demands of its current clients, as well as to handle the task of battling the competition in the acquisition of future clients.

The starting point for marketing planning in banking is the analysis of the total supply and demand of financial services, as well as the projection of future changes in the structure of the financial system [3]. In this context, each bank, based on its own comparative advantages (such as their banking products and services, territorial distribution, capital base, human resources and IT capacities), projects the future strategy of its development in order to better understand the optimal directions of future development for the purpose of achieving a position on the market (in relation to the competition and the clients) that ensures the maximization of the profit margin, market share and share capital.

Four reasons for planning have been identified in business practice [4]:

1. Planning lays out the direction of the managers' course of action in a business bank. When the employees know the direction of the further development of the commercial bank, they are familiar with the content of their own contribution to achieving the set goals; they can coordinate their activities, cooperate with each other, and do what is necessary to achieve these goals. Without planning, departments and individuals hinder the commercial bank in moving efficiently towards its goals with their individual actions with varying purposes.

2. Planning reduces insecurity by forcing bank managers to look ahead, predict the results of these changes, and formulate the appropriate response. While planning cannot eliminate the occurrence of a change or risk, managers plan in order to anticipate a possible change and find the most effective response to it.

3. Planning reduces the amount of excess activity and secondary activities. When work activities are coordinated around established plans, the excess activity is reduced to a minimum, and inefficiencies can be corrected or eliminated.

4. Planning determines the goal and standards used for control. Through control, real business operation is compared with the goals, every significant deviation is identified, and all steps necessary for the making of corrections are taken.

\section{THE ROLE OF THE BANK'S MANAGEMENT}

Banking management recognizes the importance of achieving satisfaction with service users and the role employees have in securing this satisfaction, so their goal is to have as much competent human resources as possible [5]. The basic task of the bank's management, in coordination with the marketing manager, is to decide how best to utilize resources through planning, to which banking products and services they should be allocated, in which markets to 
operate, and which target groups to address in order to achieve the highest value, e.g. increasing the market share or gaining a shareholder. In addition, the management of the bank must be able to combine the skills and techniques of planning with a market concept in which the client is at the center of attention, because only then can the bank be expected to survive in the future under attack from the competition and under increasingly uncertain business conditions on the market. The result obtained with this proactive approach to create a marketing plan is the efficient and effective use of resources, the expertise and quality that customers can recognize and the profit that the shareholders expect. In this regard, it is very important for the management of the bank to see the marketing plan not only as one of the business elements, but as a driving force and the center of the entire strategic plan of the bank.

So-called Data Base Management is used more and more often for the needs of organizing and analyzing the data necessary in the process of creating and adopting marketing plans. It includes procedures for collecting, integrating, processing and storing information on the required areas from which data is to be collected [6]. One bank can form multiple databases and use them separately or combine data from different databases. Some databases can also be purchased by the bank from external suppliers. Regarding this, one of the important decisions that a bank should make is whether to independently form its own databases based on its own software, hardware and personnel capabilities, or to leave that task to specialized software companies. This decision will depend on the size of the bank, its technological equipment and personnel. If the bank is not prepared to allocate the extra resources to all of this, it is better to leave the databases to specialized external experts. However, in that case, there is a problem of control, which may be an issue if the databases are not managed internally. Also, if the bank provides data about its clients to an external specialized agency for the compilation and management of databases, the possibility of abuse arises, i.e. disclosure of information that is considered bank secrecy. Additionally, frequent database customization is often not possible if the databases are not located in the bank itself.

\section{DEVELOPMENT POSSIBILITIES OF THE BANKING SECTOR}

In considering its strategy for the coming period, a modern commercial bank should actively anticipate and monitor the trends and perspectives of the banking and financial markets in order to gain a competitive advantage. Banks are developing new and innovative products to adequately respond to changes that come from the environment [7]. These trends are most directly reflected in the innovation of products and services, distribution channels of sales and in the better satisfaction of the needs of the banking service users. In addition, commercial banks that monitor banking trends will be less likely to come into a situation where they have to correct their strategic and marketing plans in the process of implementing action programs due to a change in the situation on the market, or the actions of the competition.

Commercial banking today is trending towards the universalizing of business operations, i.e. offering a wide range of banking products and services to the economy and the public, where a desired mix of bank operations in these two key sectors must be considered.

The main arguments for the implementation of the universal business strategy in banking are [8]:

-The strategy of cross-selling banking services,

-Resilience to fluctuations in the rate of profit and growth,

-The easier viewing of the client credit record. 


\section{SUGGESTIONS FOR THE IMPROVEMENT OF THE BUSINESS RESULTS OF BANKS}

Based on the current situation and the observed trends in the banking market, we can provide certain suggestions that banks should follow in order to improve their operations. They are:

- The reduction of bank branch offices (number and size) with negative social, political and image-related repercussions;

- Focusing efforts on making each individual branch office economically viable;

- The developing of strong partnerships with retail chains;

- The transformation of branch offices that are intended for massive dealing with the public into Financial Shops, and those intended for clients with above-average earnings into Advice Centers;

- The extension of working hours in order to gain as many clients as possible;

- Changing the exterior look and design of branch offices in order to improve their sales;

- Moving the decision-making center from the headquarters to the periphery;

- Constant expansion of loaning;

- The development and fostering of long-term relationships with clients.

\section{CONCLUSION}

Keeping in mind the environment within which banks today operate, the acceptance of the concept of marketing is inevitable. In order to avoid risk during long-term arrangements with its clients, a bank must have a clear picture of those clients as well as of the expected events during the realization of these long-term arrangements. Risk minimization and successful completion of business can only be achieved by applying the concept of marketing. Every bank should be aware that, in conditions of increased competition in the deregulated market, they must not only retain existing customers and clients but also acquire new ones through the quality of their offerings.

In other words, the application of marketing is a necessity without which there is no rational and efficient achievement of goals and minimization of business risk. The market and the competition are the strictest judges who will punish even the smallest lapse.

Other than the existence of market conditions, for the marketing concept to be applied within a bank it is necessary for the bank to have a team of good experts (the management of the bank and the staff).

The highest degree of the implementation of marketing in banking is the so-called integral marketing, which includes marketing analysis, planning and control, that is, complex marketing management, coordinated with all of the other activities of the bank, whereby marketing integrates all of the other functions under a single goal: meeting the demands of clients while achieving profit and respecting social interests.

The winners in the ever escalating rivalry of today's financial institutions will be those banks that:

- Better anticipate the needs of their clients, in this case, financial services users;

- Show greater innovation, creativity and speed in terms of organizing, introducing and developing new banking products, services and banking technologies;

- Have better staff in the top management position;

- Provide cheaper and faster services for clients than the competitors. 


\section{REFERENCES}

[1] Kotler P, Keller K., (2006.) Marketing Management, 12th edition, Data status, Belgrade, pp.412.

[2] Ratkovic M., Pavlovic M., Anđelkovic M., (2017) Comparative Analysis of Customer Satisfaction in Postal and Banking Services, International Review 1-2/2017, pp.109.

[3] Cirovic M., (1995.) Banking Management, Economic Institute, Belgrade, str. 31

[4] Robbins S., Coulter M., (2005), Management, 8th edition, Data status, Beograd, str. 159.

[5] Miletic L., Ilić M. , Kastratović E., (2018) The Role of Financial Institutions from the Aspect of Innovated Banking Products and Services as the Reply of Banks in Serbia to the Changes in the Environment, International Review 1-2/2018, pp.111.

[6] Lovreta S., Petkovic G. (2002), Trade Marketing, Faculty of Economics, Belgrade, p.420

[7] Miletic L., Ilic M. , Kastratovic E., (2018) The Role of Financial Institutions from the Aspect of Innovated Banking Products and Services as the Reply of Banks in Serbia to the Changes in the Environment, International Review 1-2/2018, pp.113.-1

[8] Cirovic M., (1995.) Bankarski menadžment, Economic Institute, Belgrade, pp. 35

[9] Milisavljevic M., (2004.) Strategic Marketing, Faculty of Economics, Belgrade, p.11. 